\title{
ANALYZING THE ACCEPTABLE PENETRATION LEVEL OF ELECTRIC VEHICLES AND PHOTOVOLTAICS IN LOW VOLTAGE DISTRIBUTION SYSTEMS
}

\author{
Vasko Zdraveski, Rubin Taleski \\ Faculty of Electrical Engineering and Information Technologies, \\ "Ss. Cyril and Methodius" University in Skopje, \\ Rugjer Bošković bb, P.O. box 574, 1001 Skopje, Republic of Macedonia \\ rubint@feit.ukim.edu.mk
}

\begin{abstract}
A b s t r a c t: Integration of photovoltaic systems (PV) into the low voltage distribution networks (LVDN) is constantly increasing. Electric vehicles (EV) and plug in hybrid electric vehicles (PHEV) are using the infrastructure of the LVDN for charging. The number of such vehicles connected for charging is increasing. When engineers designed LVDNs in the past, dispersed generation and EV were not accounted. This transition in generation and consumption will affect the voltage characteristics and will increase the inefficiency in a given LVDN. Simulation model for the energy needs of EV and PHEV is presented. The algorithm proposed for analyzing the acceptable penetration level of EV and PV in LVDN is based on stochastic method. The standard EN50160 can be used for results evaluation.
\end{abstract}

Key words: electric vehicles (EV); plug in hybrid electric vehicles (PHEV); Monte Carlo simulation; 2017 NHTS; photovoltaic

\section{АНАЛИЗА НА ДОЗВОЛЕНОТО НИВО НА ПЕНЕТРАЦИЈА НА ЕЛЕКТРИЧНИ ВОЗИЛА И МАЛИ ФОТОВОЛТАИЧНИ ЦЕНТРАЛИ ВО НИСКОНАПОНСКИ ДИСТРИБУТИВНИ СИСТЕМИ}

\begin{abstract}
А п с т р а к т: Интеграцијата на фотоволтаичните системи во нисконапонските дистрибутивни системи секојдневно се зголемува. Електричните возила и електричните возила со приклучок во мрежа ја користат нисконапонската мрежа за полнење. Бројот на ваквиот вид возила секојдневно се зголемува. Сегашните нисконапонски дистрибутивни мрежи не се димензионирани да ги прифатат новите дисперзирани производители на електрична енергија, како и електричните возила кои се приклучуваат за полнење. Оваа транзиција во потрошувачката и производството влијае на напонските прилики во мрежата и доведува до зголемување на техничките загуби. Во овој труд е презентиран компјутерски модел со кој се симулираат енергетските потреби на електричните возила. Дополнително е претставен и алгоритам со чија помош може да се анализираат дозволеното ниво на пенетрација на електричните возила и фотоволтаичните панели во дадена нисконапонска дистрибутивна мрежа. Стандардот EN 50160 е употребен за анализа и евалуација на излезните резултати.
\end{abstract}

Клучни зборови: електрични возила; електрични возила со приклучок во мрежа; симулација Монте Карло; 2017 NHTS; фотоволтаични панели

\section{INTRODUCTION}

Traditional electric power systems (EPS) produce electricity in big power plants, which are geographically far from the customers. Transmission and Distribution Network (DN) transmits electricity to customers. This way of EPS organization is gradually changing. In the last decade we witness the accelerated transition from centralized to disperse electricity sources, which are located close to the end users. In such a scenario, the role of DN is changing. Despite distribution, DN should be able to accept the energy produced from dispersed generators without threatening its normal functioning. Big PV power plants are connected to the medium voltage distribution network (MVDN). Smaller electricity sources such as small PV are getting accessible for the wide population and most often are connected to the low voltage distribution network (LVDN). 
The number of PV installed in LVDN is constantly increasing because of the subsidies, provided by national governments, and reducing of the system installation costs [1]. According to the data presented in [2], the capacity of installed PV in Europe inclusive with year 2018 is more than $400 \mathrm{GWp}$. In addition, the EU has set new criteria that should be accomplished until year 2020. It is necessary the electricity consumption to be reduced for $27 \%$. Also $27 \%$ of the whole generated electricity should be from renewable sources and the level of the greenhouse gasses should be reduced for $40 \%$ compared to the data from year 1990 [3].

The connection of numerous PV to the LVDN can cause:

- increasing of the voltages effective values (RMS),

- flicker,

- increasing of loses in the network,

- increasing of the harmonics presence in the network.

On the other hand, the level of air pollution and greenhouse gasses is growing, especially in big metropolitan areas. Therefore, the pressure on national governments is increasing to enact legislation for decreasing the impact of the internal combustion engines. Such activities is expected to cause increase in the number of EV and PHEV. The expected number of sold EV and PHEV in year 2020 will be $6 \%$ of the overall vehicles sale [4].

The charging of EV and PHEV at a certain penetration level can cause unwanted problems in certain LVDN:

- changing of the load curve with incensement of the pick power,

- decreasing of the voltages' RMS,

- increasing of the losses,

- increased presence of harmonics.

Unpredictability of consumption, because of EV and PHEV charging, can be a threat to the normal functioning of LVDN.

When EV and PHEV are present in certain LVDN, the network operator does not have information about the charging requirements of the vehicles, such as:

- energy needs,

- the time when the charging starts,

- the type of charger used (single or three phase),

- the time needed for full charging.

Using EV to reduce air pollution only makes sense if the electricity used to charge them does not cause additional air pollution and increases in greenhouse gas levels [5]. Therefore, it would be the best to use electricity generated from renewable sources for EV's charging. On the other hand, there is unpredictability of the energy production from dispersed generation from PV and this can endanger the normal functioning of the network. According to the data presented in [1] and [2], an increase of the voltages RMS in the LVDN is expected with increased penetration of PV. Especially in those periods of the day when there is no need for additional generated energy. EVs can serve as a battery tank for balancing the unpredictability in the production of small PV connected to the LVDN and the unpredictability in consumption. As it is presented in [5], $90 \%$ of vehicles are stationary at any moment, even during periods of high traffic, making them suitable for storing excess energy generated from renewable sources. By using EV as dispersed devices for electricity storage, demand site management is achieved. Additionally, by using the concept of vehicle to grid (V2G), there is possibility for the stored energy to be used when there is a need of it. However, demand site management and the concept of V2G are only possible if there is smart grid infrastructure.

Unfortunately, a large percentage of today's LVDNs do not have smart grid infrastructure installed. Therefore, the purpose of this paper is to present algorithm that can analyze given LVDN with certain EV and PV penetration level. The proposed algorithm is based on the Monte Carlo method (MCM). For this purpose, an EV energy model is presented in section 2, which is based on data from general population transportation habits. In addition, section 3 presents a method of simulating the equivalent load curve for a given household in the presence of installed PV. In section 4 is presented a draft algorithm for analyzing LVDN that has a certain level of PV and EV penetration. The conclusion and the possibility of upgrading the proposed algorithm are presented in section 5 .

\section{EV ENERGY MODEL BASED ON SURVEYS}

In order to develop a computer model for the daily energy needs of an EV, it is necessary to have the following information:

- daily driving distance $(\mathrm{km})$,

- arrival time = connection time to the LVDN,

- vehicle type ("sedan", "van", "pickup van" and "SUV"),

- charger type (single-phase or three-phase),

- consumption [kWh / km],

- battery capacity, 
- location (bus) where EV is connected for charging.

We used data for daily driven distances from surveys that register people transportation habits. Although surveys generally refer to vehicles with internal combustion engines, they still contain sufficient data that we used to create a computer model for the daily energy needs of EV. An example of such a survey is a survey conducted in the United States called "National Household Travel Survey" (NHTS) [6]. It was last conducted in 2017 and covers respondents across whole territory of the US. It contains data on over 900,000 individual trips collected between April 2016 and May 2017. Since the purpose of these surveys is to analyze the transportation habits of people in the US and not to design an $\mathrm{EV}$ computer model, part of the data is filtered.

Some of the recorded trips are made using public transport, hiking, cycling or boat travel. Therefore, for the purposes of creating EV energy model, it is only necessary to use data from those trips made with vehicles type "sedan", "van", "pickup van" or "SUV". For each vehicle, there is information about:

- the number of trips made with the vehicle on a daily basis,

- driven kilometers,

- time when the trip started,

- time when the trip ended.

Summing the kilometers traveled on each of the individual trips, we obtain data on the total kilometers traveled per day for each vehicle.

To determine the moment when EV is connected to LVDN, we used the "NHTS" data again. If it is assumed that the vehicle owner will connect for charging to the LVDN immediately upon arrival, then the time when the last journey is ended in a day, can be treated as the time of connection. Additionally, the NHTS survey provides information on the distribution of vehicles by their type and is shown in Table 1.

Table 1

Distribution of vehicles by their type (\%)

\begin{tabular}{cccc}
\hline \hline "Sedan" & "SUV" & "Van" & "Pickup van" \\
\hline 50.72 & 25.47 & 5.37 & 18.44 \\
\hline \hline
\end{tabular}

Distribution of vehicles by their type is essential information in EV modelling because different types of EVs have different battery capacity. Additionally, due to their different weight, different types of EVs have different energy consumption per kilometer. Data of energy consumption per kilometer as well as battery capacity information for different types of EV can be found in [7].

There is still insufficient information in the literature on the distribution of EV chargers by their type. However, as it is shown in [8], we set the charging current to $10 \mathrm{~A}$, and the charger efficiency to $\xi=0.88$. With this type of EV charger modelling, its power depends only on whether it is single-phase or three-phase.

Any of the households powered by a certain LVDN can own an EV. Since it is not possible to determine the charging location for a given $\mathrm{EV}$ in a certain LVDN, we select the charging bus randomly.

\section{SIMULATING HOUSEHOLD LOAD CURVE}

\section{a) Low voltage distribution network description}

Figure 1 shows the low voltage distribution network that can be used for testing the proposed model. It is IEEE test network with frequency of 50 $\mathrm{Hz}$. The test network has a radial topology and it is connected to a medium voltage distribution network over $800 \mathrm{KVA}$ transformer. The total length of the cable lines of the entire LVDN is 1,431 meters. The LVDN serves 55 households. In the literature [9], there are additional data on the LVDN cables and parameters of the transformer.

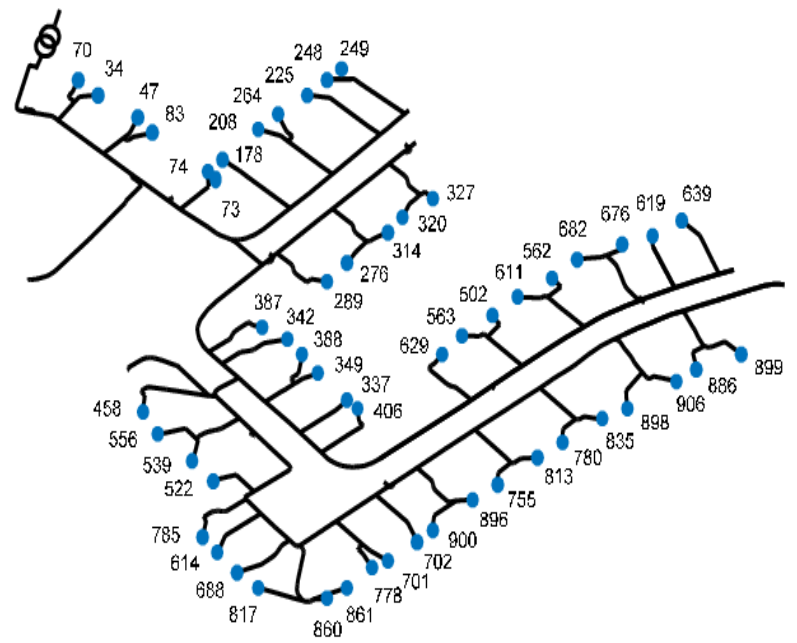

Fig. 1. Low voltage distribution network

\section{b) Household load curve modelling}

In the data [9], daily load curves for each of the 55 households are provided. The load curves are with one-minute resolution. As the EV energy 
model presented in Section 2 is simulated at 15-minute intervals, it is necessary to model the load curves of the households with the same resolution.

Figure 2 depicts the shape of the load curve for households connected to nodes 225 and 835 . We calculate the reactive power of the households by taking into account the power factor of $\cos \varphi=$ 0.95 .

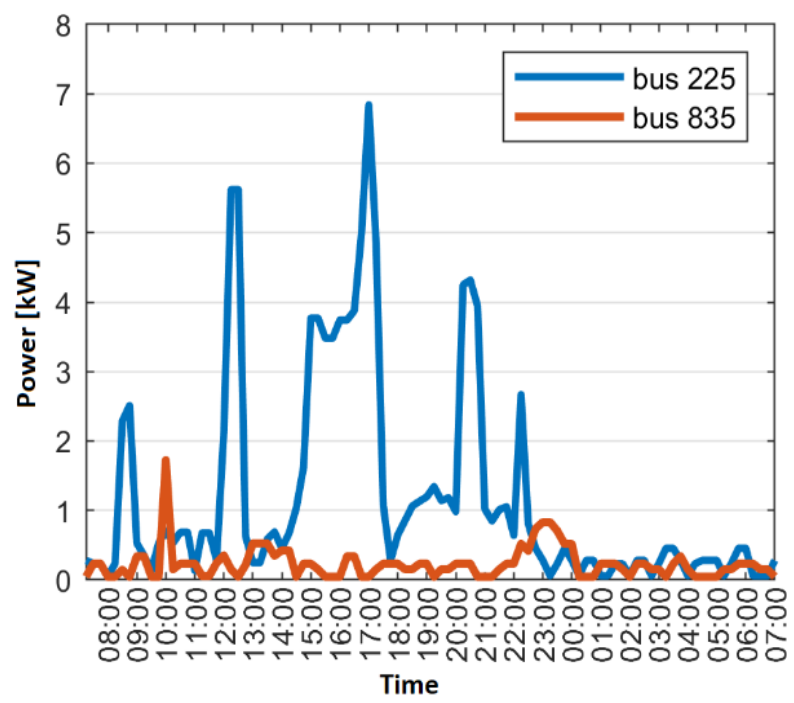

Fig. 2. Daily load curves

In order to increase the reliability of the modelling results, it is also necessary to take into accountthe unpredictability of consumption when modelling the load curves of general household consumption. Expressions 1 and 2 are used to introduce a certain level of unpredictability into general household consumption.

$$
\begin{gathered}
P_{i j}=\operatorname{random}\left(\mu_{i}, \sigma_{i}\right), \quad i=1,2 \ldots N_{\text {bus}} ; \\
j=1,2 \ldots 96, \\
\mu_{i}=P_{\text {discrete } i, j}, \sigma_{i}=0.1 \cdot \mu_{i},
\end{gathered}
$$

where $P_{i, j}$ is the power of the $i^{\text {th }}$ household at time interval $j . \mu_{i}$ and $\sigma_{i}$ are the mean value and the standard deviation by which the uncertainty is introduced. According to expressions 1 and 2, the power needs for each household, at each time interval is determined as random value by the normal distribution, with mean and standard deviation. The mean value is defined as the discrete value of the power for the household and the time interval. The standard deviation is set to be $10 \%$ of the mean value. When such a model is set, for each MC iteration, the load curve will be similar in shape to the baseline, but with different values for the respective time intervals.

\section{c) Modelling the output curve of photovoltaic panels}

Solar radiation in a particular geographical area is the basic data needed to simulate the generation of electricity by the PV. For this purpose, we recommend to use the data from [10]. Figure 3 depicts the average solar radiation for the month of July (maximum radiation) and December (minimum radiation) over a period of one day without clouds on the territory of the City of Skopje. The data relate to a flat plate with a surface area of one square meter, positioned at an angle of $22^{\circ}$ to the horizontal plane. Choosing an angle of $22^{\circ}$ assumes that the PVs are mounted on the roof of a house.

To calculate the generated electrical power in $\mathrm{kW}$, we will use expression 3:

$$
P=\frac{G}{1000} \cdot A \cdot e_{p v} \cdot e_{s y s},
$$

where $G$ is solar radiation expressed in $\mathrm{W} / \mathrm{m}^{2}, A$ is the surface of the installed PVs, $e_{p v}$ is the efficiency of photovoltaic modules when converting from solar to electrical power, and $e_{s y s}$ is the efficiency of the system when converting from DC to AC.

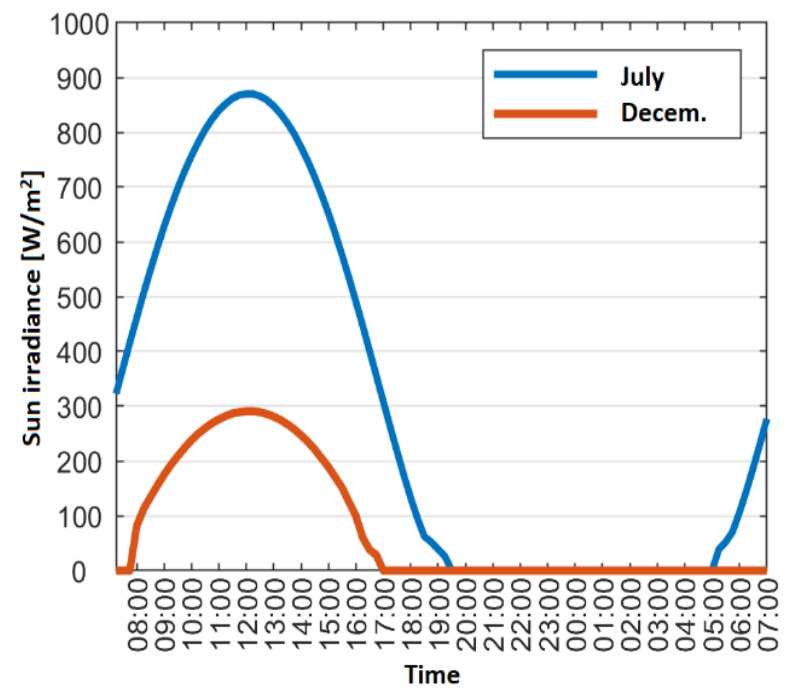

Fig. 3. Sun irradiance

The reliability of the simulation results depends from the unpredictability of the electricity generated by the PV. For this purpose, we suggest random selection of the solar radiation curve. The curves shown in Figure 3 are used as limit values. Therefore, the daily solar radiation curve to which PV, mounted on houses roofs will be exposed, will vary between the characteristic curves for a sunny day in July and December. This simulates solar radiation for days of different months. Daily variations in the intensity of solar radiation due to the 
appearance of clouds are not taken into consideration. In addition, due to the inability to predict the roof area on which PVs can be installed, we propose area $A$ to be randomly selected. The minimum area on which PV can be installed is $10 \mathrm{~m}^{2}$ and the maximum is $50 \mathrm{~m}^{2}$. For the efficiency of photovoltaic modules in the conversion of solar energy to electricity, as well as for the efficiency of the DC/AC system, catalog data for devices of this type will be used [11].

Figure 4 shows the PV power plant output curves exposed at a solar radiation depicted in Figure 3. The surface of the installed PV is $30 \mathrm{~m}^{2}$. The calculations are based on data on "BP Solar Saturn" photovoltaic modules with conversion efficiency at solar radiation from $e_{p v}=14,3 \%$ [11]. The efficiency of a converting DC/ AC system is $e_{p v}=90 \%$.

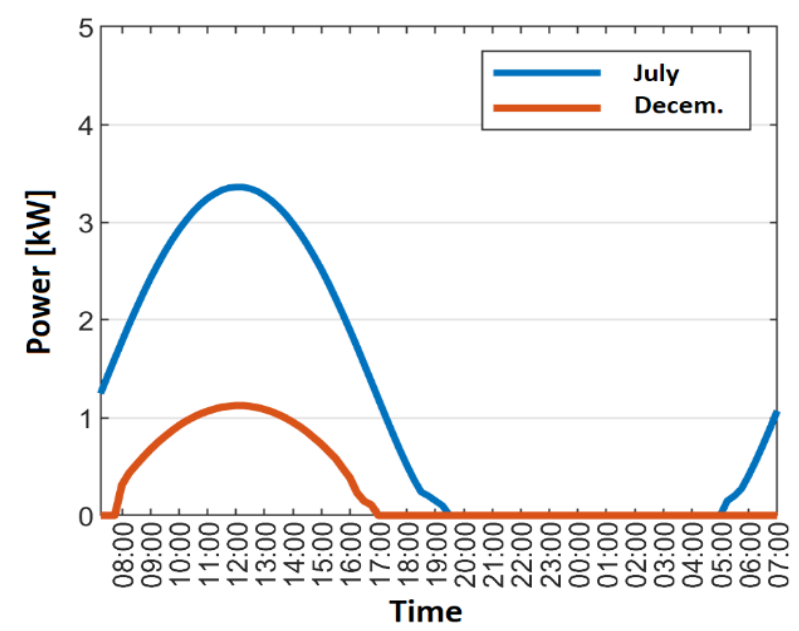

Fig. 4. Energy produced from PV

\section{PROPOSED ALGORITHM}

In order for the DN operator to analyze the permissible level of EV and PV penetration in a given LVDN, it is necessary to have data on:

- households that own EV,

- the capacity the EV that need to charge,

- when EV connects the network for charging,

- households that own small photovoltaic plants,

- installed capacity of photovoltaic,

- daily production of the installed photovoltaic power plants.

Since the DN operator cannot provide the necessary data and most of it is unpredictable, the best approach in analyzing such problems is through MC simulation. In this problem-solving approach, an attempt is made to try as many configurations as possible and to draw appropriate conclusions based on the large number of outputs. The input data in the analysis should be randomly selected but at the same time, it should be function from a natural dependence.

For a simpler explanation of the algorithm based on the MC method, the diagram shown in Figure 5 can be used. First, we need to know the number of households that a given LVDN serves. According to data available in [6], each household owns an average of 1.95 vehicles. At a predefined level of $\mathrm{EV}$ penetration in one area, the number of $\mathrm{EV}$ in the area served by a given LVDN can be calculated by:

$$
N_{e l \_v e h}=1.95 \cdot N_{\text {house }} \cdot \frac{p l_{e v}}{100},
$$

where the level of EV penetration in a given LVDN is presented. In addition, at a predefined level of PV penetration, the number of households that have installed a small photovoltaic power plant is calculated by:

$$
N_{\text {house_pv }}=N_{\text {house }} \cdot \frac{p l_{p v}}{100}
$$

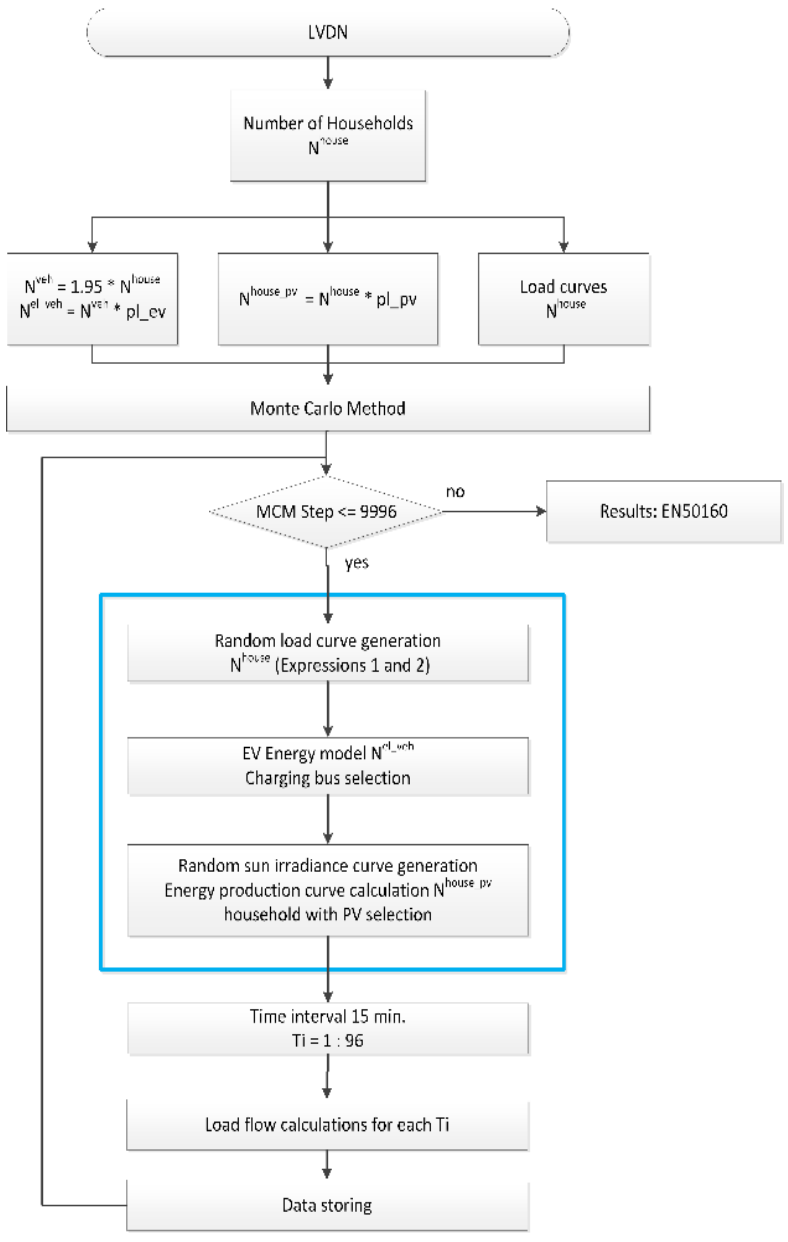

Fig. 5. Proposed algorithm based on MCM 
In the proposed algorithm, the number of $\mathrm{MC}$ steps is 9996, which corresponds to 1428 weeks. By choosing a relatively high value for the number of MC steps, it is more likely that all critical combinations of input variables are taken into account. After developing the algorithm, it is necessary to check if the number of steps is sufficient or there is a need to increase the number of steps. If the analysis shows that the number of steps is oversized, MC steps should be reduced in order to obtain a more efficient algorithm.

One MC step simulates one day. The number of time intervals per day is 96, so LVDN is analyzed in 15 minute intervals. As the power flows are calculated every 15 minutes, there is a possibility for a detailed analysis of the LVDN load flow, in particular the effective values of the node voltages required to evaluate the quality of electrical energy provided by the operator. For simpler analysis of the results, the day starts at 07:00.

Section 3 describes the procedure for simulating the household load curve. Its shape depends from the following three curves:

- a curve that defines the standard household consumption,

- curve that defines the energy requirements for charging an EV (if the household owns an EV),

- curve defining the electricity produced by the PV (if the household owns a PV).

The distribution of EV and PV across households is randomly selected. It may happen that one household in one MC step owns an EV, and has a PV installed. With each new MC step, EV and photovoltaic power plants are redistributed to other households, randomly selected, and thus different load curve is generated.

Since the number of outputs is large, 96 time intervals calculated for all 9996 days, the simplest way to analyze voltage profiles is to use the standard EN50160. According to this standard, the effective value of the voltage should be within $\pm 10 \%$ of its nominal value, more than $95 \%$ of the time in one week. Since the number of analyzed weeks is 1428 , it is easy to analyze what percentage of weeks for each household the EN50160 standard is not fulfilled.

\section{CONCLUSION}

By developing the proposed algorithm presented in this paper, it is possible to analyze the permissible level of PV that can be installed in a certain
LVDN. The presence of EV in the LVDN can increase the permissible level of PVS that can be installed in the certain LVDN. In addition, it can be analyzed what is the reason for not fulfilling the standard: high penetration rate of EV or PE. Such results also provide an opportunity to deepen the analysis for introduction of economic packages that would reward EV owners if their vehicles were used for balancing, in situations where there is a surplus of electricity generated by the PV in the LVDN.

\section{REFERENCES}

[1] Nousdilis, A., Chrysochos, A., Papagiannis, G., Christoforidis, G.: The impact of photovoltaics self-consumption rate on voltage levels in LV distribution grids, In: 11th IEEE International Conference on Compatibility, Power Electronics and Power Engineering (CPE-POWERENG), Cadiz, Spain, 2017.

[2] Nousdilis, A., Christoforidis, G., Papagiannis, G.: Active power management in low voltage networks with high photovoltaics penetration based on prosumers' selfconsumption, Applied Energy, pp. 614-624 (2018).

[3] European Union: On the energy performance of buildings. Directive 2010/13/EU of the European Parliament and of the Council, Official Journal of the European Communities, May 2010.

[4] Voelcker, J.: Global Market Review of Hybrids and Electric-Drive Vehicles, May 2009.

[5] Kong, P., Karagaiannidis, G.: Charging schemes for plugin hybrid electric vehicles in smart grid: A Survey, IEEE Access, 2016.

[6] 2017 NHTS Data User Guide, Administration, Federal Highway, 2018.

[7] Shafiee, S., Fotuhi-Firuzabad, M., Rastegar, M.: Investigating the impacts of plug-in hybrid electric vehicles on power distribution systems, IEEE Transactions on Smart Grid, Vol. 4, no. 3, pp. 1351-1360 (2013).

[8] Hui-ling, L., Xiao-min, B., Wen, T.: Impacts of plug-in hybrid electric vehicles charging on distribution grid and smart charging, In: IEEE International Conference on Power System Technology (POWERCON), Auckland, New Zealand, 2013.

[9] The IEEE European Low Voltage Test Feeder, IEEE PES Distribution Test Feeders, Feb 2015. [Online]. Available: http://sites.ieee.org/pes-testfeeders/.

[10] Suri, M., Huld, T., Dunlop, E., Ossenbrink, H.: Potential of solar electricity generation in the European Union member states and candidate countries, Solar Energy, Vol. 81, no 10, pp. 1295-1305 (2007).

[11] Thomson, M., Infield, D.: Impact of widespread photovoltaics generation on distribution systems, IET Renewable Power Generation, Vol. 1, no. 1, pp. 33-40, (March 2007). 